\title{
情報誘導によるグリオーマ手術
}

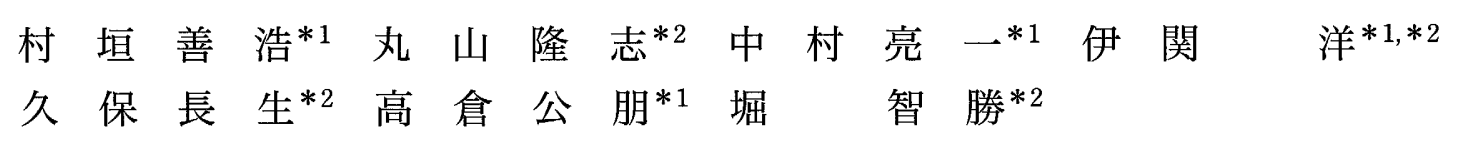

\section{Information-guided Surgery for Glioma Removal}

by

Yoshihiro Muragaki, M.D. ${ }^{* 1}$, Takashi Maruyama, M.D. ${ }^{* 2}$,

Ryoichi Nakamura, Ph.D. ${ }^{* 1}$, Hiroshi Iseki, M.D., ${ }^{* 1, * 2}$, Osami Kubo, M.D. ${ }^{* 2}$, Kintomo Takakura, M.D. ${ }^{* 1}$, and Tomokatsu Hori, M.D. ${ }^{* 2}$

from

${ }^{* 1}$ Faculty of Advanced Techno-surgery, Institute of Advanced Biomedical Engineering and Science, Graduate School of Medicine and ${ }^{* 2}$ Department of Neurosurgery, Neurological Institute,

Tokyo Women's Medical University

The relationship between radical resection of glioma and patient outcomes has been controversial, partly because of selection bias, publication bias, and methodological flaws, particularly in regard to the estimation of the glioma removal rate. A recent study used volumetric analysis of removal rate to demonstrate that radical removal resulting in better patient outcomes. However, new removal strategies to maximize removal rate and minimize complication rates are needed to further improve outcomes. The goal of the present study was to develop an algorithm for "information-guided surgery", in which surgeons rely on objective information rather than subjective experience to determine whether glioma removal is feasible. An operating system (intelligent operating theater) was developed that detects anatomical, functional, and histological information obtained by intraoperative magnetic resonance images/navigation, mapping/monitoring data, and data from frozen section, evaluate the validity of the data, and subsequently integrates the data with update navigation. The present study focused on the benefits and drawbacks of functional information and introduces illustrative cases of information-guided surgery.

(Received October 3, 2005; accepted November 17, 2005)

Key words : mapping, monitoring, brain tumor, awake craniotomy

Jpn J Neurosurg（Tokyo） $15: 384-395,2006$

\section{はじめに}

神経膠腫（glioma）における手術の目的は，(1)組織診

断, (2)圧迫解除 (症状改善, 生命危機解除), (3)てんかん 発作コントロール, (4)腫瘍細胞数隇少 (cytoreduction) による生命予後改善などが挙げられる（Fig. 1)，それぞ
れの目的に応じて必要とされる摘出量・摘出度が異なる ため, 手術計画立案の際のゴール設定が最も重要となっ てくる，例えば，大きな腫愓であっても組織診断のみが 目的であれば生検術となるが, 症状の改善や生命危機解 除を目指す場合には，亜全摘出以上の摘出が必要と考元 られる。てんかん発作のコントロールのためには全摘出

\footnotetext{
${ }^{* 1}$ 東京女子医科大学大学院先端生命医科学研究所先端工学外科 $/$ T 162-8666 新宿区河田町 8-1〔連絡先：村垣善浩〕

Address reprint requests to: Yoshihiro Muragaki, M.D., Ph.D., Faculty of Advanced Techno-surgery, Institute of Advanced Biomedical Engineering and Science, Graduate School of Medicine, Tokyo Women's Medical University, 8-1 Kawada-cho, Shinjuku-ku, Tokyo 162-8666, Japan

*2東京女子医科大学脳神経外科
} 


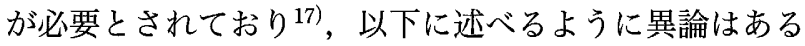
が, cytoreduction による生命予後改善は, 全摘出に近い 摘出が必要であろう.

目的により摘出目標が異なるのとともに，治療方針に よっても摘出目標が異なってくる，例えば，星状細胞腫 (astrocytoma；AC) でも退形成性星状細胞腫（anaplastic astrocytoma；AA)でも, 放射線治療を行う施設であれば, 生検術で星状細胞系腫瘍であることが確認できればよ い.しかし，ACで経過観察，AA で放射線治療を行うと いう治療方針を持った施設の場合, 画像で悪性度の高い と予想される部分を含めた, ある程度の摘出を行う必要 がある。乏突起細胞腫系の腫瘍組織が混在する腫瘍に対 しプロカルバジンを含めた化学療法を施行する方針の施 設では, ある程度の摘出を行い詳細な組織学的検討が必 要となる.

われわれの基本方針は，上記(1)（3)の達成と，(4)の可 能性を持つ神経膠腫の “全摘出”である。“全摘出”には 範囲が広い順に, 組織学的, 画像上, 肉眼的（執刀外科 医の術中判断）全摘出がある（Fig. 1) が，客観性，再現 性から, 現時点での目標は画像上の全摘出としている. 個人差がある機能局在を持つ脳に発生した境界不明瞭な 病変の “全摘出” と, 神経学的合併症を最小限に抑える という脳神経外科の基本との両立一一最大限の摘出と最 小限の合併症一にに新しい手術戦略が必要である。

新しい手術戦略として, 主に 3 種類の客観的な術中情 報を用いた情報誘導手術を提唱している。術中 MRI やナ ビゲーションなどの解剖学的情報, 術中電気生理学的検 査や覚醒下手術での神経症状などの機能的情報, 凍結標 本による術中組織診断や 5-アミノレブリン酸（5-ALA） による腫瘍蛍光染色 ${ }^{18)}$ を用いた組織学的情報であり, い ずれも客観的で信頼性の高い術中情報である.

本稿では, 神経膠腫の摘出術と予後や合併症との関係 に関する論文紹介を行い, 情報誘導手術の実際を述べる。 中でもマッピングやモニタリングなどの機能的情報に焦 点を当てる。というのは, 最大限の摘出を行う場合, 最 も大きな制約条件は神経機能の温存であり, 制約条件を 徹底活用一一本質的な機能野を知り，それを損傷しない 最大限の摘出範囲決定一するためには正確な機能的情 報が必要である。しかし，機能的情報は，高度になれば 他の情報と比べデー夕取得が難しく, 解析が技術的に困 難なことがあるため, 代表例として言語機能に関し効率 的な方法と合併症予防について述べる。 そして最後に, 多種類の術中情報を扱う場合の実例と問題点を述べ，解 決するための戦略デスクを紹介する。 また手術技術論と しては, 脳の重要な機能領域 (eloquent area) に存在す

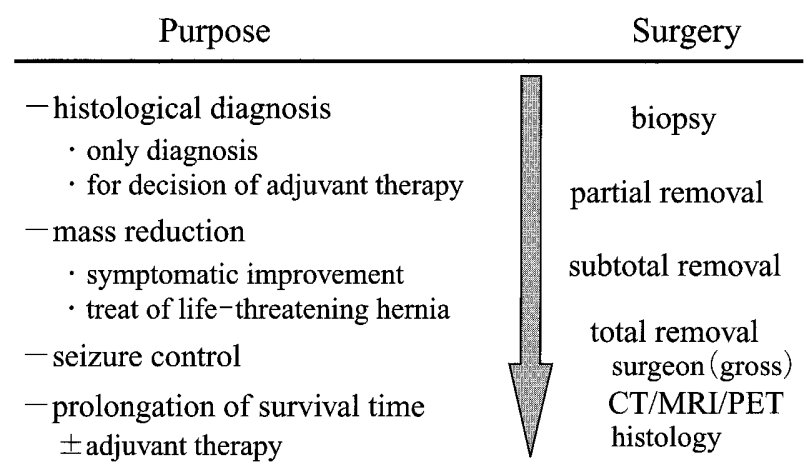

Fig. 1 Resection planning for glioma surgery

る神経膠腫以外の病変の摘出にも応用できると思われる ので参考にしていただきたい.

\section{神経膠腫摘出術と予後や合併症との関係 \\ 1 悪性神経膠腫の広範囲摘出と予後改善に関す る議論}

悪性神経膠腫（grade III, IV）において，広範囲腫瘍 摘出と予後改善との相関には議論が多い. 90 年代の代表 的な 9 研究のうち, 前向き研究 (prospective study) を 含めた 6 研究で, 覀性神経膠腫に対する積極的な外科手 術が有意に生存率と相関していたが，3 研究では有意差 を認めなかった ${ }^{11)}$ 。また神経膠腫摘出術に関する 120 論 文での検討では, $72.5 \%$ の論文で摘出術の効果あり, $27.5 \%$ で効果なしとの報告であった ${ }^{31)}$ 。これら, 結果の 違い（controversy）の原因としては，さまざまな研究方 法の bias（対象症例の梽意的な選択による selection bias や陽性結果を示すほうが出版されやすい publication bias）や，診断基準や定義が研究間で異なること，また 研究方法の不備が指摘されている，中でも最も大きな問 題は，摘出度の定義や評価方法の違いである．用語の定 義が異なれば結果の解积も異なってくるが, 例えば, ヨー ロッパの腫瘍研究グループである EORTC (European Organization for Research and Treatment of Cancer) では, “total resection”は $90 \%$ 以上摘出と定義しており ${ }^{15)}$, 日 本での全摘出とは異なる. Albert $ら^{1)}$ は, 同一症例群で 全摘出できたかどうかを，外科医の印象 (判断), 術後 CT, 術後早期 MRI（72 時間以内）によって判断した場 合，全摘出率（全症例中全摘出症例の割合）がそれぞれ 70\%，29\%，17\%と大きく異なっていたことを示した. 加えて, 外科医の術中判断で全摘出できたとする症例は 生存期間が 38 週で, 術後早期 MRI で全摘出と判断した 症例での生存期間が 68 週であった。すなわち, 神経膆 腫摘出の評価方法によって, 同じ全摘出といっても予後 
が異なることを示した．先ほどの 120 論文の検討でも， 摘出度評価の方法 (total resectionの定義と測定法) の記 載がないのが $62.5 \%$ もり, 方法の記載がある $37.5 \% の$

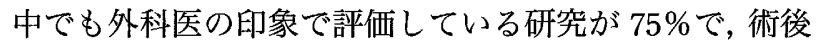
画像での評価による研究の $24 \%$ (術後 CT や MRI での評 価 $21 \%$, 体積を計測しての評価 $3 \%$ ）を大きく上回って いる31).

次に, 摘出度を術後 MRI で評価するとしても, どの部 分を画像上の腫瘍領域として面積を算定し, 摘出率を評 価するかが問題となる、神経膠腫細胞の組織学的な進展 範囲の評価が可能であれば, 最も正確な組織学的な摘出 度が算出できるが，生体で確認することは困難である。 そこで次善の客観的な評価方法として, 画像上で腫瘍範 囲を定義する方法が考えられる。論文上では, 神経膠芽 腫 (glioblastoma；GBM) は造影領域 ${ }^{16)}$, 造影されない AC は $\mathrm{T} 1$ 強調画像で低信号域を対象とする報告 ${ }^{36)}$ が多い. 剖検例であるが, GBM は造影領域外の T2 強調画像高信 号域まで浸潤しているという報告 ${ }^{14)}$ があるにもかかわら ず，この定義に従えば，造影領域のみを摘出した場合に 100\%摘出（全摘出）となることに批判がある. しかし, この場合の全摘出は組織学的全摘出を意味するのでな く，定義された “MR 画像上の全摘出” であることを強 調したい.また，AA な゙で, 境界は比較的明膫な低吸 収域であるが内部が一部造影される腫瘍の場合の体積の 算定方法や, 造影されない腫瘍でも $\mathrm{T} 1$ 強調画像と $\mathrm{T} 2$ 強 調画像の異常域が大きく異なる腫瘍面積の評価方法は新 たな基準が必要である。一方, 新たな評価方法としてメ チオニン PET 画像が注目を浴びている.メチオニン取り 込久と増殖能が相関する ${ }^{5)}$, PET 陽性部分の全摘出が予 後良好と相関している, GBM で摘出後の残存 PET 陽性 部位が再発巣と一致していた症例などの報告があり ${ }^{19)}$, 浸潤領域の同定に期待できる.

摘出率を術後 MR 画像の造影領域の体積で計測して 評価した Lacroix ら ${ }^{16)} の 416$ 例 GBM の報告, あるいは, 術後 CT や MR 画像で評価した日本脳腫瘍全国統計 ${ }^{33}$ に おける $\mathrm{GBM}$ 症例の 5 年生存率の検討では, 前者は $98 \%$ 以上摘出群, 後者は $95 \%$ 以上摘出群と全摘群が他群に比 較し予後良好との結果であった。 また，AA を加えた日 本脳腫瘍全国統計 6,398 例の検討でも，全摘出群の 5 年 生存率 $40 \%$, $95 \%$ 以上摘出群 $22 \%$ ，それ以下 $10 \sim 15 \%$ と各群間でそれぞれ有意差を認めた。両報告とも摘出度 と予後に関連を認めたが, 全摘出に近い摘出でないと予 後に影響しないとの結果であった。

\section{0 神経翏腫の広範囲摘出と予後改善に関する議 論}

摘出度と予後との関係は, “良性”神経膠腫 (low-grade glioma）でも controversial である。“良性”神経膠腫は, 悪性と比較して予後調査期間が長く必要なため, 最近の 報告でも調査開始が古く，摘出度の評価が画像でないこ とが多い.ヨーロッパの EORTCによるテント上 lowgrade glioma 288 例の予後調査 ${ }^{29)}$ では, total removal 群が 多変量解析では有意差がないという結果だが，外科医が 判断した $90 \%$ 以上摘出を total removal 群としている.日 本脳腫瘍全国統計での AC の 4,460 例検討では, 全摘出 群, $95 \%$ 以上摘出群, $75 \%$ 以上摘出群, $50 \%$ 以上摘出群, 生検群の 5 年生存率は, それぞれ $88 \%, 75 \%, 64 \%, 59 \%$, $54 \%$ となり, $75 \%$ 以上摘出している 3 群は他の群と比較 して有意差を認めたが，テント上に限定した場合，2,602 例では全摘出群と $95 \%$ 以上群がそれ以下の群と比較し 有意差を認め, やはり全摘出に近い摘出が予後に影響す るとの報告であった。

“良性” 神経胗腫と呼ばれることがある ACであるが, 5 年生存率は，日本全国統計でも $67 \% ，$ EOTRG でも low-grade glioma は $65 \%{ }^{29)}$ と, 他の癌と同等か, それ以 下の治療成績である，GBM のみ予後の悪さ $(6.3 \%)$ が 強調されているが, “中間型”とよばれる AA でも 5 年 生存率は $23 \%$ でしかない.よくデザインされた前向き研 究の結果を待たなければいけないが，他臟器転移が稀で 再発の 9 割以上が局所であること, エビデンスレベルは 高くないが全摘出に近い摘出が予後改善を示唆している ことから，物理的に取り去る確実な局所治療である手術 の役割は大きいと考えられる。 また全摘出に近い摘出が できた場合，免疫系を抑制するステロイド剤が不要にな

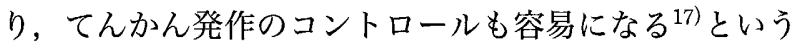
利点もある。

\section{3 神経膠腫の全摘出率}

さて，現状でどれくらい神経膠腫を全摘出しているか というと，文献上 $6.2 \sim 71 \%$ と，報告により幅がある. 前述のように, 全摘出の定義や評価方法，また母集団が 異なっているからである，例えば，母集団に生検例を含 めない場合は全摘出率が上昇し，また開頭症例を選択す る際に selection bias が入る危険性がある. 生検例も含め た場合，全摘出した症例の割合は $6 \sim 20 \%$ 程度と考光ら れるが，全国統計では $\mathrm{GBM} 6.6 \% ， \mathrm{AA} 6.7 \%, \mathrm{AC} 10 \%$ と 低いものであった．従来の方法でいかに困難かが想像で きる. 
Fig. 2 Information-guided surgery for glioma resection

To maximize resection rate and minimize complication rate, we need various kinds of information, such as, anatomical, functional, histological, and metabolic information. Anatomical information is integrated to functional and histological information by update navigation (arrow, see Fig. 4 and 5. UN: update navigation). Functional information has priority over other types of information (triangle). For example, functional tissue in tumor shown by mapping and navigation would be preserved. Metabolic information such as PET can be fused with MRI (line) and is associated with histology (dotted arrow).

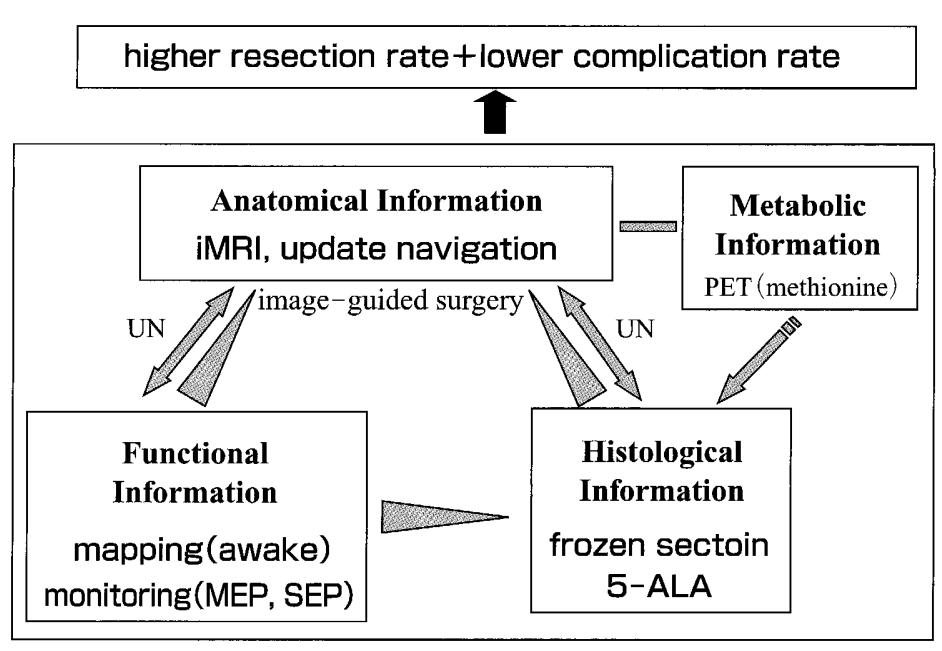

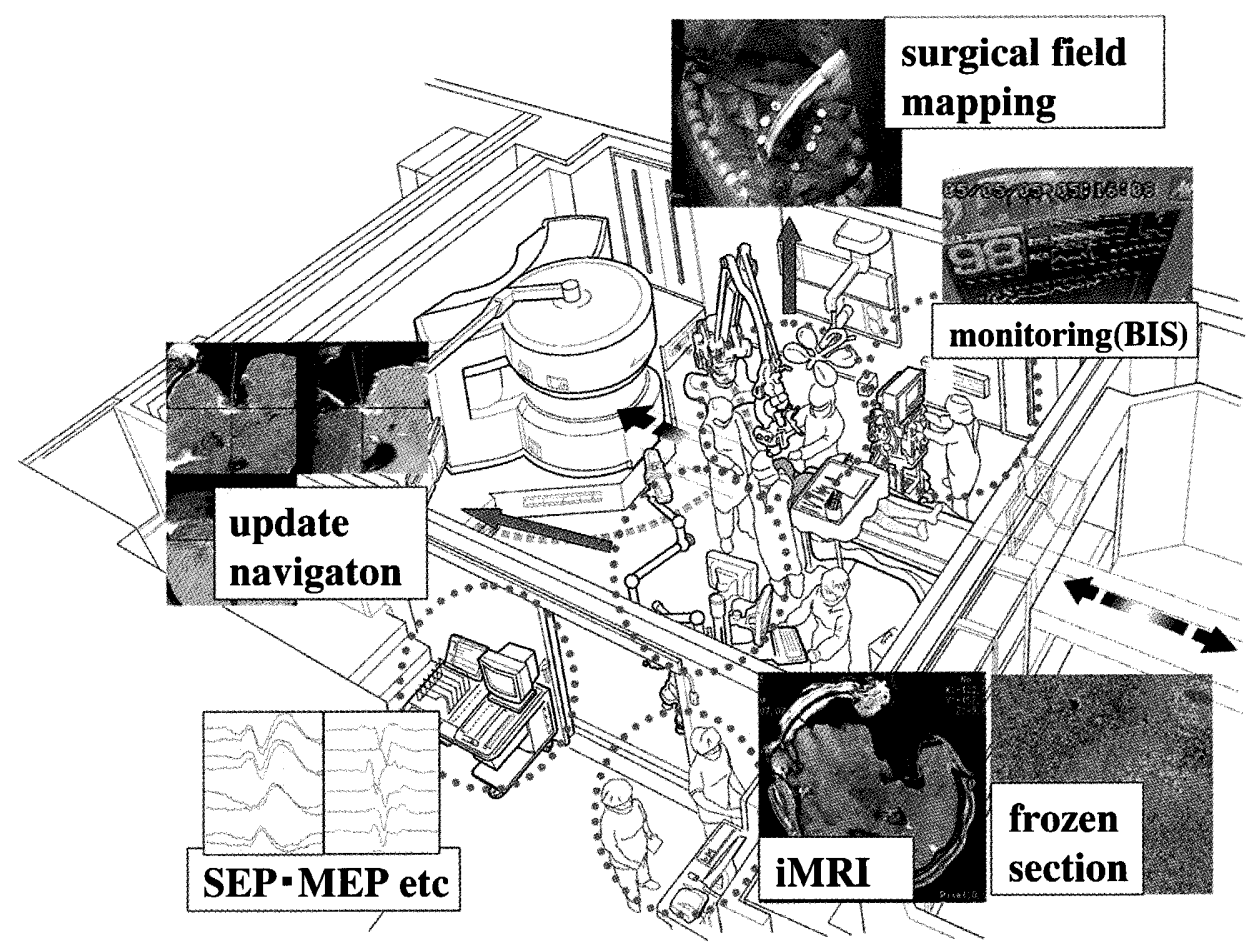

Fig. 3 Intelligent Operating Theater for information-guided surgery Intelligent Operating Theater gains various kinds of information. iMRI : intraoperative MRI.

\section{4 神経膠腫摘出術における合併症率}

一方，摘出率向上を目指した場合の合併症の増加が懸

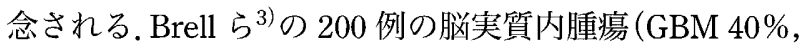
AA 21\%, AC 23\%, Meta 17\%） に対する開頭術の合併 症の報告では，神経学的欠損症状を含めた合併症率は $27.5 \%$ であり, 術後神経学的欠損症状と有意に関連して いたのは, テント下腫瘍, 放射線治療の既往, 再手術で あり, eloquent area かどうかや摘出度との関連は認めな かったという。.Duffau ら)は, eloquent area の glioma 摘
出手術を報告している．皮質と皮質下マッピングを施行 し, $30 \%$ の症例で画像上全摘出, $50 \%$ の症例で要全摘を 施行した. 術直後の神経学的合併症状は $80 \%$ と高率に出 現するものの，3 カ月以内にそのうちの 95\%が回復し， 症状残存したのが6\%であったという. Eloquent areaの 神経膠腫の拡大摘出を目指した場合，一過性にでも非常 に高い確率で神経症状がでるが，皮質下を含め詳細に マッピングを施行していけば，永続的な合併症状は低減 できると考えられる。 
さらに合併症率を低隇し摘出率を上げるためには，神 経膠腫に対する新たな手術戦略が必要と考えられる。

\section{神経膠腫摘出のための情報誘導手術（Fig. 2)}

CT や MRI などの解剖学的画像情報を用いた定位脳手 術やナビゲーション装置による手術は，画像誘導手術と 呼ばれている，神経膠腫の摘出量を最大化し，合併症を 最小化するためにわれわれが提案する新たな手術戦略 は，画像情報以外のさまざまな情報を利用した手術一 情報誘導手術一である ${ }^{13)}$. さまざまな術前情報を利用 して事前に手術計画を立案し, 術中の判断材料にするこ とは，一般手術で行われている。しかし，術前情報のみ では摘出その他の術中変化を予想はできても正確に知る ことはできないため，情報誘導手術では主に術中情報を 用いる、例えば, 従来の術前画像を基にしたナビゲーショ ンでは, 髄液排出や腫瘍摘出などによって, 術中に起こ る脳の変形 “brain shift” による誤差が $4 \sim 8 \mathrm{~mm}$ 発生す る ${ }^{25)}$ といわれている。これを脳の変形が起こった後，す なわち術中に MRI を撮影し，その画像を再度ナビゲー ションに登録して用いれば（update navigation；UN)，誤 差の少ないナビゲーション23) となる，当然，術中 MR 画 像により顕微鏡下でも境界不明膫な神経膠腫の残存部分 を MR 画像上で知ることは最大の利点で, 摘出率向上に 有用である。

現在, 情報誘導手術では, 術中 MRI とUNによる解 剖学的 (形態学的) 情報, 術中生理学的検査や患者の術 中神経症状などから得られる機能的情報，そして凍結標 本による術中組織診断や 5-ALA に上る腫瘍蛍光染色 ${ }^{18)}$ を用いた組織学的情報を中心に手術摘出を決定している が (Fig. 3)，症例によりPET による代謝情報も参考にし ている，PET は術前情報であるが，MRI との fusion 画 像があれば術中 MRIにより update した情報として利用 できる。

目的達成のためには，個々の情報をより正確にするこ と,術者がより直感的に理解できる提示方法にすること, さらに異なる種類の情報を統合することも必要である. この情報統合の基になるのが, 術中 MR 画像による UN である．例えば，電気刺激による脳機能マッピングによ り言語反応が出た場合 (機能的情報)，その部位を UN で表示すれば（解剖学的情報との統合）, 異常 (おそらく 腫瘍）陰影内であるかが確認できる，また UN 上で摘出 部位が腫瘍陰影境界に近づいた場合（解剖学的情報）に, その部分の組織を術中組織診断で腫瘍細胞が残存してい るかを検討（組織学的情報との統合）すれば，摘出範囲
の意思決定に有用である.

\section{情報誘導手術における機能的情報}

神経膠腫摘出術では, 機能的情報が重要である. Intraaxial 腫瘍である神経膠腫を, 画像上でも全摘出を目指し た場合, 腫崵の全表面積分, “正常脳” との境界を切開す ることになり，合併症を予防するためには，腫崵の周囲 脳の機能的情報が必要になる，また，機能を持った組織 が神経膠腫内に存在した症例を $7 \%$ (28/413 例) に認め たとの報告があり ${ }^{28)}$ ，腫瘍摘出自体で機能障害を起こす 可能性が否定できない.

したがって, eloquent area 近傍あるいは内の神経膠腫 では, 合併症予防のため機能的情報が必要になる. 現在, 機能的情報を知るための非侵襲的な方法として，脳回や 脳溝などの解剖学的特徵からの類推, fMRI や MEG など がある. Diffusion tensor imaging や tractgraphy は生体で 神経線維を描出する方法であるが，錐体路のように明確 な機能を持ったものを対象にした場合には，機能に関す る有用な情報を与える解剖学的情報となる。一方，侵襲 的なものとして，脳血管撮影時の麻酔薬による誘発テス 卜 (Wada テスト $)^{39)}$, 慢性硬膜下電極や覚醒下手術の際 のプローブを介した電気刺激による方法などがある。こ れらの情報を用いてどのような形で手術を行うかの戦略 決定までのプロセスを，言語関連の機能野周辺に存在す る病変で述べる。

\section{1 言語関連の機能部位}

機能野同定を行うか否かの最初の選別は，病変の解剖 学的部位による，部位は，運動性言語中枢では下前頭回 後方部の三角部と弁蓋部（Brodmannの 44 野，45 野） から中心前回下部にかけて, 感覚性言語中枢では側頭葉 上中下側頭回後半部 (41 野, 42 野, 22 野, 37 野), そ して頭頂葉の緑上回, 角回 (40 野, 39 野) が相当する. 運動言語野と感覚言語野を結ぶとされている弓状線維 (上縦束) 近傍病変でも適応となる。また, 側頭葉内側の 海馬も言語性記憶に関連しており，その他島回も挙げら れる．上記部位の周辺に病変があり，かつ以下で述べる 方法で病変側が優位半球である場合，あるいは優位半球 である可能性が少しでもある場合，機能野同定を行う候 補となる。

\section{2 優位半球決定}

右利きの $99 \%$ 方左優位半球であるといわれているた め，右病変では機能野同定が必要ないように思われる。 
しかし, 自験例でも右利きで右優位半球の症例が $9 \%$ (8/ 91 例) 存在し, うち半分の 4 症例が右病変であった。 し術前に優位半球同定を行っていなければ全身麻酔での 手術となり, 予想外の失語症を合併した可能性があった。 さて, 優位半球同定には非侵襲的な fMRI がよいと考え られるが, 摘出範囲の決定のためには信頼性は低い.マッ ピングや術後症状による優位半球同定結果との比較にお いて, fMRI による解析では 14\%（7/50 例）で反対側に シグナルが出ていたというからである ${ }^{38)}$.すなわち侵襲 的ではあるが, 優位半球同定には脳血管撮影に抢ける麻 酔薬による誘発テスト（Wada テスト）が必要である。 ただ Wada テストによる優位半球決定も経験が必要であ る. 麻酔薬の注入量が多ければ意識障害が前景となり検 查が行えず, 少なければ症状発現の時間が短すぎて検査 が困難になる。また，両側優位半球の場合ではそれぞれ の半球で異なる言語症状が出て判断が困難となる. 判定 が困難な場合を含めて, 優位半球が病変と反対側にある と確定できない場合は, 以下に述べる方法で機能野同定 を行う。さらに安全性を優先するのであ机ば右利きで左 優位半球と確認でき, 右に病変がある場合を除き, 機能 野同定が推桨される。

\section{3 機能野同定方法の選択}

機能野同定のためには, 現在, 電気刺激による脳機能 マッピング2227)が最も信頼の高い方法である. fMRI は優 位半球同定と同様に感受性が低く, やはり fMRI の結果 のみで手術摘出範囲を決定できない. 呼称夕スクによる fMRI での陽性部位は, 電気刺激で反応があった部位の $22 \%$ しか同定できず，呼称と動詞生成タスクを合わせて ようやく $59 \%$ の部位を同定できたのみである ${ }^{34)}$. 機能野 同定の実行には, (1)埋込んた慢性硬膜下電極を介した 電気刺激22), (2)賞醒下手術時に刺激器を用いた電気刺激 があり，われわれは，一般的ではないが適応があれば(1) と(2)両方を行うことにしている. (1)は，十分な時間をか けて完全な覚醒下の状態で行えるために, より偽陰性や 偽陽性の少ない，より正確なマッピングを施行できるか らである。

慢性硬膜下電極を埋め込まない一般的な方法では, 覚 醒下手術にはさまざまな目的がある。(1)脳皮質電気刺激 による皮質マッピング, (2)腫瘍摘出中の脳白質 (皮質下) 電気刺激による皮質下マッピング, (3)摘出中に機能が温 存されているかどうかの神経機能モニタリングである。 慢性硬膜下電極の埋め込んだ場合は, (1) 硬膜下電極で のマッピングの結果確認となり時間短縮が計れ, 主な役 割は(2)と(3)になる。 また施設により, 開頭後摘出前の皮
質マッピングが終了すれば全身麻酔に移行する方法を採 ることがあり，この場合(2)と(3)は行わない.

\section{脳機能マッピング・モニタリング}

覚醒下手術による腫瘍摘出には 3 つの目的がある. (1) 脳皮質電気刺激による皮質マッピング，(2)腫瘍摘出中の 脳白質（皮質下）電気刺激による皮質下マッピング, (3) 摘出中に機能が温存されているかどうかの神経機能モニ タリングである21).

\section{1 皮質マッピング}

覚醒下手術でのマッピングは，覚醒下とい兄ども静脈 麻酔薬は投与されており完全な覚醒下ではないことと時 間的な制約があることを念頭に置いて行わなければなら ない.ママッピング時の偽陽性（症状が出たが言語野でな い）は覚醒不良が原因のことが多く，偽陰性（症状が出 ないが言語野）は電気刺激の条件や夕スクが時間的な制 約のために適切でなかったことによることが多い. 前者 を改善するためには，十分な局所麻酔による鎮痛を行っ た後に, マッピングの際は静脈麻醉をほぼ offにし，よ り覚醒に近い状態で行う。後者の電気刺激の条件には, 刺激部位, 刺激強度, 刺激時の言語夕スクと 3 つの変数 があり,さまざまな組み合わせを術中に網羅的に行うこ とは不可能である。したがって効率的なマッピングを行 うことが必要で，参考となる重要な報告を挙げる。

刺激部位では Broca 野の位置がシルビウス裂から上方 に平均 $1.7 \mathrm{~cm}$, 中心溝から前方に平均 $1.4 \mathrm{~cm}$, 三角部の ascending ramus とシルビウス裂の交点から後上方に平 均 $2.3 \mathrm{~cm}$ であった ${ }^{322}$. また刺激強度では, 矩形波, 200 msec, $50 \mathrm{~Hz}$ の条件で, 運動野, 前頭葉言語野, 頭頂側 頭葉言語野の刺激閾值がそれぞれ $8.4 \mathrm{~mA}, 9.3 \mathrm{~mA}$, $12.3 \mathrm{~mA}$ であったという30). 言語夕スクは物品呼称と反 応性呼称の組み合わせが言語野同定の感受性が高かっ $た^{12)}$.

また従来，電気刺激により言語停止する部位は言語野 とされていたが，それ以外に陽性運動野（発語に関連す る筋肉の収縮により言語停止する）と䧔性運動野（電気 刺激をすると共同運動が停止する反応で発語も含まれる ため言語停止する）の可能性がある。言語野が他の 2 種 と独立して同定でき, 腫瘍外であった場合（自験例で $52 \%)$, 摘出を開始できる。しかし, 陽性運動野しか同 定できない場合（自験例で $48 \%$ ）もあり, 刺激条件が不 十分で言語野が同定できていないか（刺激強度やタスク が不十分な場合や言語野皮質が脳溝側や脳裂側皮質に存 
在している場合), 実際独立した言語野が存在しない場合 が考えられる，自験例では後者の場合が多く，言語停止 の部位が腫瘍内でなけ机ば一般摘出と同様である。しか し前者の場合では, 再度腫瘍上のマッピングを詳細に 行ったうえで摘出を開始し，摘出中も神経症状に一層注 意し，慎重に摘出するべきである。

\section{2 白質マッピングとモニタリング}

白質マッピングは, landmark がなく手術操作の途中で 施行しなければならないことなどから，皮質マッピング と比較し技術的にもより困難である。 そこで, 解剖学的 知識を持つたうえでの効率のよいマッピングが必要であ る.皮質マッピングで機能がないことを確認していれば, マッピングを行った脳回部分の摘出は原則可能である が, 脳溝の最深部より深い白質部分はマッピングが必要 になってくる．また，モニタリングで言語の応答が流啺 でなかった場合やナビゲーション上言語関連線維に近い 部分を操作する場合などにも，マッピングで確認しつつ 摘出を進めていく，電気刺激プローブ先端を摘出胿の壁 に当て, 皮質刺激で陽性所見が得られたのと同じ電流, または高電流の条件で電気刺激を施行しマッピングを行 う。もし症状発現が確実であれば操作をいったん中止し, 症状回復後白質マッピングにより再度確認することが必 要である。また白質マッピングで反応が出た場合，その 部位での操作は一般的に中止すべきである，反応が出た 場合, 刺激部位と実際の神経線維とは非常に近い $(5 \mathrm{~mm}$ 程度かそれ以下）ことをナビゲーションで確認できた症 例があるからである，例外としては連絡線維でも反応が 出現することがあり, 判断には操作部位の解剖学的情報 が必須である。

さて, 言語機能に関連する神経線維として, 弓状束 (arcuate fasciculus) と梁下束 (subcallosal fasciculus) が 挙げられる ${ }^{8)}$. 弓状束は, 前頭葉後部と側頭葉上部を結 ぶ線維として Dejerine らが発見者の名にちなみ Burdach's arcuate fasciculus $\varepsilon$ 命 名 $l$, Wernicke $\ell$ Geschwind が損傷により伝導失語になることを報告し た. また, 解剖学的には前頭葉と側頭・頭頂・後頭葉を 結ぶ上縦束の一部であると考元られている。最近の tractgraphy の所見から, 弓状束は, 単に前頭葉と側頭葉 を結ぶ線維のみならず，浅層では前頭葉と頭頂葉，頭頂 葉と側頭葉を結ぶ線維から成るとされている ${ }^{4)}$.この弓 状束を保存するために摘出時に注意すべき場所は, 前頭 葉腫瘍を例に取ると, 上前頭回腫瘍では摘出腔底部外側, 中前頭回腫瘍では底部全体，下前頭回腫瘍では底部吻側 (中前頭回側) である.
覚醒下手術中の神経機能モニタリングは最も信頼でき る方法であり, 術後出血や梗塞がない限り偽陰性は少な い，長時間のモニタリングになることもあるため，タス クだけでなく一般の会話を行うことも多い.

\section{3 合併症}

主な合併症は, 疼痛, 吐気嘔吐, 感情失禁, 媛攣発作, 頭蓋内圧充進，局麻中毒などがある，最も注意すべき痤 攣発作は, 自験例で $12.8 \%$ に発生しており, 他シリーズ でも $16 \%{ }^{6)}, 5.6 \%{ }^{37)}$ と頻度の高く，危険性の高い合併症 である。まず刺激を低電流 $(1 \mathrm{~mA}$; 刺激器の表示は 0.5 $\mathrm{mA}$ だが矩形波のため最大振幅は $1 \mathrm{~mA}$ ) から始め, 徐々 に増加させていく(1 $4 \mathrm{~mA}$ 程度). 導入初期は刺激間で 30 秒以上の間隔を開けるべきだが, 経験により十分な監 視のもと刺激間隔を短縮していく．ストリップ電極で電 気刺激後発作波（after discharge）をチェックし, 発生し た場合には刺激間隔をさらに開けるか，いったん他の部 位を刺激するべきである。しかし， after discharge が続 く時や部分発作が発生した場合には対処が必要である が, ジアゼパム (セルシン $\left.{ }^{\circledR}\right)$ は，以降マッピングやモ ニタリングが継続できなくなるため，使用は避けたい． そこで有用な方法は, 冷リンゲル液を直接脳にかける方 法であり，マッピング時には氷水を用意しておくべきで ある ${ }^{35)}$. 術前頻回に発作があった症例は要注意であり, また刺激後 5 分以上経ってから全般化した症例もあり, 直後に after discharge がないからといって油断はできな い.

上記の方法でわ机われは, 1997 2004 年末までに神経 膠腫 39 例の覚醒下手術を予定し，38 例（97\%）でマッ ピングが施行でき, うち 29 例 $(76 \%)$ で摘出終了まで モニタリングが完遂できた。、ッピング不能であった 1 例は, 導入時にせん妄状態となったためであり, 全身麻 酔で摘出を施行した。またモニタリングが完遂できな かった 9 例の原因は, 覚醒不良 6 例, 痤攣 2 例, せん妄 1 例であったが，うち再手術を施行したのが 1 例であっ た。このような経験から, 覚醒下手術を施行する場合, 術者はマッピングやモニタリングが不能になった時を想 定して対処法を考えておかなければならない。またこ の 39 例の平均摘出率は $92 \%$ でった。

\section{4 マッッ゚ング・モニタリングの要点}

このように, マッピングやモニタリングが必要な eloquent area 近傍の手術でのコッは, 初期操作で症状出現 した場合，それ以降の操作の良し悪しの判断ができなく なるため, 安全なところから危険なところへ摘出を行う 

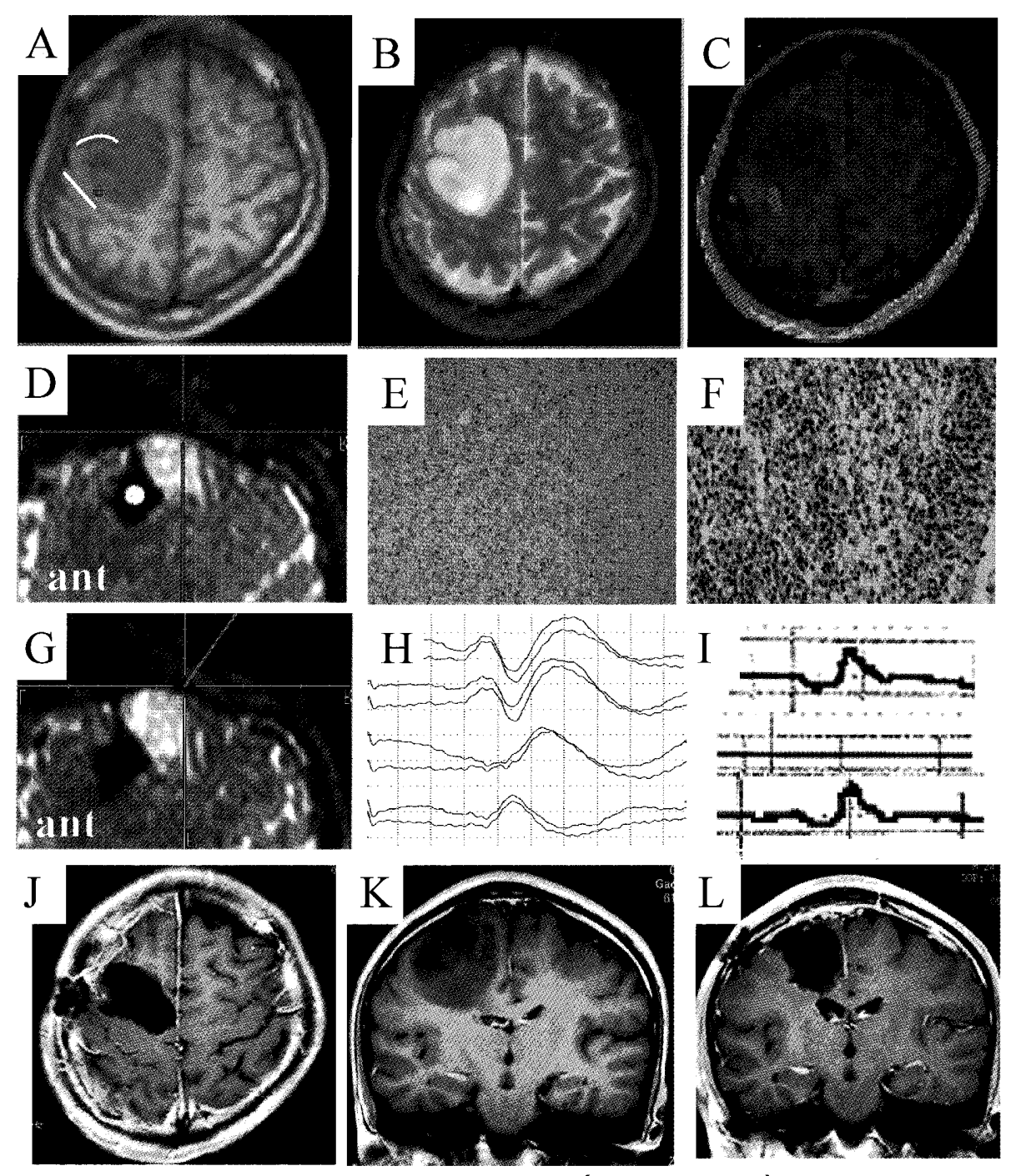

Fig. 4 Illustrative case 1 (see text p.393)

ことである。もし症状が出現したら，いったん別の場所 を操作する。再度同じ場所の操作で症状の再現性あれば, 重要な脳組織が非常に近いと考元, 原則その部分は保存 する．ただ例外的に，事前にインフォームド・コンセン トによる方針で摘出を優先するとなった場合には摘出を 行うこともある。

\section{外科情報学 “Surgical Infomatics"}

情報誘導手術では多種多様のデー夕を扱うことになる が，その解析や解积には，術中という特殊な環境におけ る新たな考え方, すなわち外科情報学 “Surgical Infomatics”が必要である。求める情報は客観性や再現性が高い 情報であり, 求められる情報は外科医が術中に取得が困 難な情報である。例えば, 神経膠腫には術中 MRI やナビ ゲーションは必要であるが, 一般的な髄膜腫での必要性
は低い。

\section{1 術中データの必要条件と情報システムのロバ ストネス（頑健性）}

手術にはさまざまな制約があるため，術中デー夕取得 には必要条件を満たさなければならない、すなわち確実 性が高いこと, 短時間で測定結果が出ること, 簡便な測 定方法であること，術野の滅菌性を保てることあるいは 滅菌可能な道具であることなどが挙げられる。例えば, $50 \%$ 患者でしか取得できない測定方法だとしたら， データが取れる前提で手術計画を立てられないし, 解析 に何時間も必要な方法は当然術中デー夕として使用でき ない，ただ確実性が高い方法であっても，デー夕が取れ ない場合も想定しておかなければならない，前述の覚醒 下手術でも全身麻酔に移行したものが $2 \%$ あり, マッピ ングができず摘出目標を下げざるをえない。術中モニ夕 

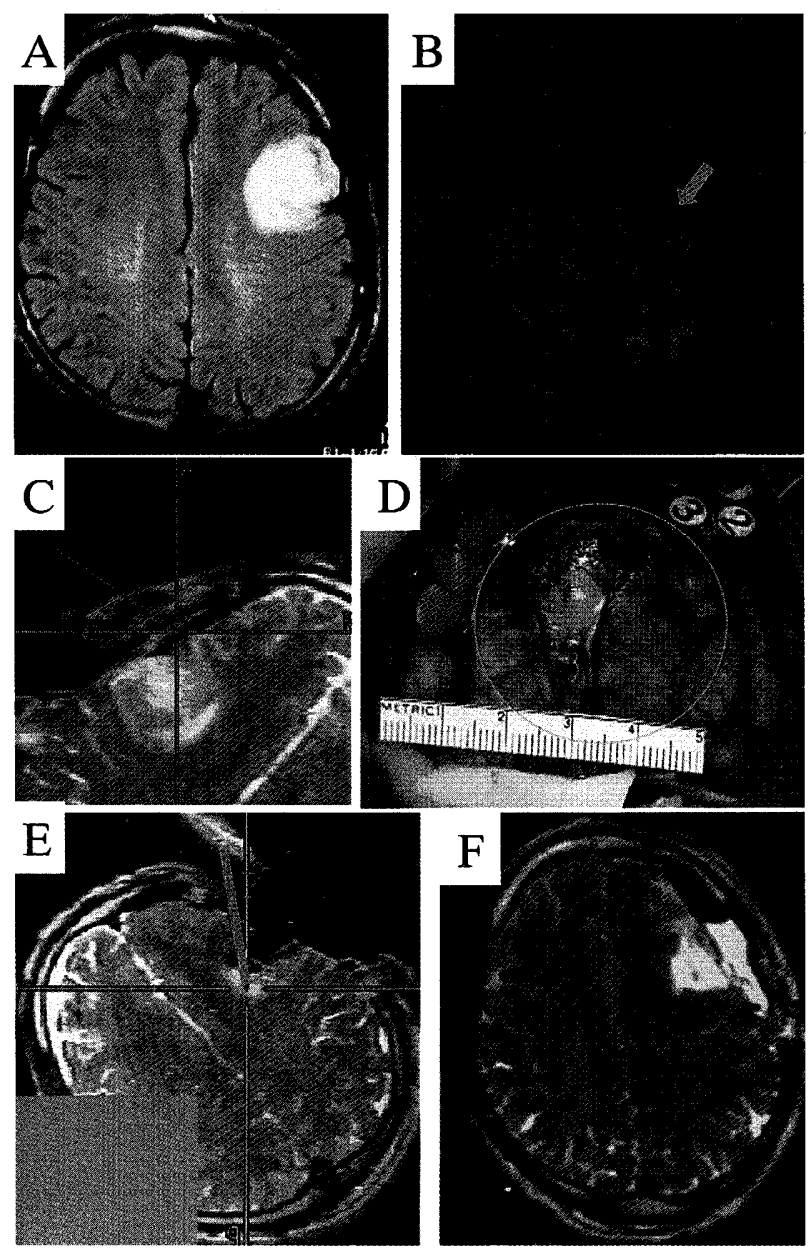

Fig. 5 Illustrative case 2 (see text p.393)

リングの経皮質運動誘発電位（MEP）でも $8 \%$ の症例で 安定した電位が取れなかったとの報告がある ${ }^{24)}$ ，対策と しては，他の代替あるいは類似の方法を用意して掞くこ とが挙げられる，方法に冗長性を持たせることでシステ 厶自体のロバストネスを高める。われわれは, 症例 1(Fig. 4）のような運動野内や近傍の神経膠腫では, 覚醒下手 術による症状モニタリング, 経皮質 MEP, 経頭蓋 MEP と 3 種類の方法を準備したうえで摘出を行うことが多 い．前述のとおり，それでも情報を得られない場合の対 策，摘出目標を下げる，あるいは 2 期的手術とする，な ぞを考慮しておくことも必要である。

\section{2 術中データの誤差と検査結果の特異性・感受 性（偽陽性・偽陰性）}

次に, デー夕自体に計測誤差があり, デー夕を解釉し

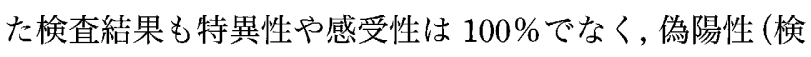
査は陽性で疾患が陰性）や倄陰性が存在すること, 計測 条件や閾值の設定によりこれらも変わることも理解して
おくべきである，例えば，ナビゲーションを用いる場合 も，(1)ステム自体の機械的な䛊差，(2)画像の歪みによ る誤差, (3)マーカーずれなどによる登録の誤差, (4)術中 の臟器変形による誤差などさまざまな誤差が存在する。 (4)は詳しい研究が行われており, 脳表実質で平均 $8 \mathrm{~mm}$, 深部実質で平均 $4 \mathrm{~mm}^{25)}$, 白質線維は 8〜 $15 \mathrm{~mm}$ 移動して いた ${ }^{26)}$. 術前画像をナビゲーションに用いる場合, この 術中移動は誤差となる。また，術中モニタリングとして 感覚誘発電位 (SEP) の 423 例の検討では, 検査の偽陰 性（術中 SEP に変化なく術後欠損症状が出現）を $19 \%$, 偽陽性を 7\%に認めたという ${ }^{40)}$. しかし，比較的高い偽 性率だからといって 5.5\%の患者で久損症状を予防でき たというモニタリングの有用性 ${ }^{40)}$ を否定するものではな い. 検査には偽性率が必ずあり，その特性を理解したう えで検查デー夕を解釈することが必要である.

\section{3 同系統情報における異種類データの扱いと異 系統情報での不一致の場合の対応}

同系統の多種類のデー夕を取得した場合, 状況ごとに どのような優先順位で用いるかの問題もある。例えば, 腫瘍の存在を示すものは術中 MR 画像と術中迅速組織 診断と5-ALAによる術中蛍光診断がある。それぞれの 特性があり，それを活かした摘出方法を施行している. 大部分は外科医の判断と術中 MR 画像と UNにより摘出 し, 周辺は 5-ALA で発光しているところを摘出し, 最 終摘出腔周辺は術中迅速診断を施行する。このデータが 異なる結果の場合（例えば 5-ALA では光っているが MRI 上は等信号域) の意思決定は, 術前の目標による. すなわち，画像上全摘出なのか，5-ALA 陽性部位全摘出 なのか, 組織学的全摘出を目指すかによって判断が異な る.

異系統のデータでもジレンマが生じる，最も大きな問 題は, マッピング上反応が認められた部位 (機能的情報) が UN で腫瘍が疑われる部位（解剖学的情報）にあった 場合である，最大限の摘出を目指せば摘出となるし，最 小限の合併症を目指せば温存となるというジレンマがあ る. 合併症の危険性を十分承知したうえで摘出を優先す るという患者側の意志がはっきりしている場合を除き， われわれの基本方針は温存である，その理由として，神 経膠腫摘出後機能野が移動したとの症例報告9) が挙げら れる. 文献では, 初回手術時, 神経膠腫内にマッピング で反応があった部分を温存したが, 初回手術時マッピン グで反応があった部分が再発時にマッピングで反応がな くなっており摘出できた症例が報告されている9). また, てんかんの症例でも再手術で機能野の移動が認められた 
症例の報告 ${ }^{20)}$ がある。このような摘出と温存という別の 方針を示唆する異なるデータが存在するジレンマの際 に，あらかじめ基本的な方針がなければ意志決定は非常 に困難になる．すなわち「デー夕は意志決定のプロセス があって初めて “情報”となる」10)のである，施設での基 本方針とそれに患者側の意向を加えた症例ごとの方針を 術前に決定しておくことが必要である.

情報誘導手術によって摘出した運動野，言語野の代表 例を提示する。

\section{【症例 1】(Fig. 4)}

\section{患 者: 28 歳, 男性}

現病歴 : 病攣発症. 右前頭葉の $\mathrm{T} 1$ 強調画像で低信号域 (Fig. 4A), T2 強調画像と FLAIR 像で高信号域 (Fig. 4B, K）を示し，ガドリニウムで造影されない腫陽. SEP に て中心溝を同定し (Fig. 4A 後方線と Fig. 4H), 腫瘍は中 心前回 (運動野) 内と上中前頭回後部（前運動野と補助 運動野）であることを確認した（Fig. 4A）。覚醒下で電 気刺激を行うと, 中心前回後部 (Fig. $4 \mathrm{~A}$ 丸, 機能的情 報）に手の運動野が認められ，その部位はUN で腫瘍院 影外であった(解剖学的情報との統合). 前運動野の摘出 を行い, 病理は astrocytomaであり（Fig. $4 \mathrm{E}$; 組織学的 情報)，一般的には運動野内腫瘍を温存することも考えら れた.しかし Methionine PET で中心前回がより hot のた め (Fig. 4C; 代謝情報), 生検を行ったところ anaplastic astrocytoma（Fig. 4F; 組織学的情報）であり, UN を利 用し中心前回内腫瘍の摘出を開始した。部分発作による Todd's palsy を認めたため, 自発運動によるモニタリン グ不能となり, 運動誘発電位にてモニタリングを施行し た。電位が一時消失したが, 操作中止により振幅が回復 した（Fig. 4I; 機能的情報）。画像上全摘出し (Fig. 4J, L), 一過性麻痺は出現したが 1 週間で回復した。職場復 䚻し, 術後 1 年だが再発を認めていない。

\section{【症例 2】 (Fig. 5)}

\section{患 者: 33 歳, 右利き男性}

現病歴：痓攣発症. 左中前頭回に $\mathrm{T} 1$ 強調画像で低信 号, T2 強調画像, FLAIR 像で高信号域（Fig. 5A）の辺 縁が比較的明瞭な腫瘍。Diffusion Tensor Imaging では, 上縦束は腫瘍後内側緑と接していた（Fig. 5B）. Wada テ ストで言語優位半球が左であり, 硬膜下電極を埋め込夕 同時に行つた生検術では glioma との診断であった. 硬膜 下電極と覚醒下手術によるマッピングは一致しており, 4 筒所の言語野 (Fig. 5C: ナビゲーション上の言語野 3 , Fig. 5D: 数字 1 4, ) 口の運動野 (Fig. 5D 緑), 陰性運
動野（Fig. 5D 青）が区別でき，腫瘍陰影内になく，そ れぞれ腫瘍（Fig. 5D 黄円）の後方, 後下方, 前下方で あった（Fig. 5D）。覚醒下手術にて言語機能をモニタリ ングしつつ摘出を行った. 術中 MRI で確認された後, 内 側の残存腫瘍を摘出している時に, 発語が流暢でなく なったため, Ojamann の刺激器でその皮質下の部分を電 気刺激したところ, 物品呼称と動詞生成が不能であった. ナビゲーションで確認したところ（Fig. 5E の交点）, T2 強調画像の高信号域と正常との境界であり（解剖学的情 報と機能的情報の統合), 術中迅速診断で組織学的にも明 らかな腫揚細胞塊を認めないため（組織学的情報 Fig. $5 \mathrm{E}$ ）摘出を終了した. 画像上全摘出し（Fig. 5F), 術後 一過性の軽度失語が出現したが回復し, 復職した.

\section{おわりに}

神経翏腫の過不足のない摘出には解剖学的情報による 画像誘導手術のみでは不十分であり，われわれは情報誘 導手術を提案した。“全摘出”という目標に対し, 最大の 制限条件は神経機能の温存であり, 正確な機能部位を知 ること（機能的情報）は, 制限条件のための温存範囲を 最も小さくし，最大限の摘出を可能にする。また浸潤性 の神経膠腫を摘出するには, 腫場細胞の存在部位を知る こと（組織学的情報）は本質的な情報である。これらの 情報は “外科医の新しい目”となるべきものであり，各 情報を統合し用いるのが情報誘導手術である.

一方で多系統, 多種類のデー夕を取得することになり， 同系統異種デー夕の解釈と優先順位, 多系統情報の統合 と取捨選択など新たな課題が発生する。手術戦略デスク はアップデートした各術中情報を多面表示するととも に, tractgraphy などの有用な術前情報を同時に表示する ことにより，摘出範囲の意思決定を行う場となる，さら にこの “外科医の新しい脳”となる戦略デスクは, 術中 取得デー夕と術後治療成績を解析し, 手術の工程解析に フィードバックすることで, 成功確率の高い手術戦略を 作成していく，またこの戦略デスクは, 手術のイベント レコーダーとして合併症が起こった際の原因解析を可能 にし，医療安全に貢献すると考えられる，現在，“外科医 の新しい手”となる手術用ロボットを開発中であり，自 動抽出した病変を自動焼却する, すなわち入力出力とも デジタル化した精密誘導手術を目指している。 


\section{謝 辞}

PET 検査をご協力いただいた中部療護センター 篠田 淳先生, 三輪和弘先生，中山則之先生に深謝致します．神経膠腫臨床を打手 伝いいただいた 田中雅彦先生，天野耕作先生，井上龍也先生，電 極埋め込みやマッピングを施行していただいた 落合 卓先生，山 根文孝先生に深謝致します.また覚醒下手術のご指導賜りました横 浜旭中央病院 谷川達也先生, 白河病院麻䣷科 国沢 卓之先生, 東 京女子医科大学麻醉科 尾崎 畺先生, 野村 実先生, 長田 理先 生, 倉田二郎先生に深謝致します，インテリジェント手術室の構築 と手術器具開発にあたり, 東京女子医科大学先端生命医科学研究所 先端工学外科分野の大学院生 杉浦 円氏 (日立製作所), 南部恭二 郎氏（東芝)，藤田吉之氏 (日本光電)，谷口拡樹氏，小澤紀彦氏 (日立メディコ)，インフォコム社 鈴川浩二氏のご協力をいただい たことを深謝致します。

また本研究の一部は，新エネルギー・産業技術総合開発機構 （NEDO）による平成 15 年度産業技術研究助成事業の助成を受け た.

\section{文 献}

1) Albert FK, Forsting M, Sartor K, Adams HP, Kunze S: Early postoperative magnetic resonance imaging after resection of malignant glioma: Objective evaluation of residual tumor and its influence on regrowth and prognosis. Neurosurgery 34: 45-61, 1994.

2) Berger MS : Functional mapping-guided resection of low ${ }^{-}$ grade gliomas. Clin Neurosurg 42: 437-452, 1995.

3) Brell M, Ibanez J, Caral L, Ferrer E: Factors influencing surgical complications of intra-axial brain tumours. Acta Neurochir (Wien) 142:739-750, 2000.

4) Catani M, Jones DK, Ffytche DH: Perisylvian language networks of the human brain. Ann Neurol 57:8-16, 2005.

5) Chung JK, Kim YK, Kim SK, Lee YJ, Paek S, Yeo JS, Jeong JM, Lee DS, Jung HW, Lee MC: Usefulness of $11 \mathrm{C}-$ methionine PET in the evaluation of brain lesions that are hypo-or isometabolic on 18F-FDG PET. Eur J Nucl Med Mol Imaging 29: 176-182, 2002.

6) Costello TG, Cormack JR: Anaesthesia for awake craniotomy: A modern approach. J Clin Neurosci 11:16-19, 2004.

7) Duffau H, Capelle L, Denvil D, Sichez N, Gatignol P, Taillandier L, Lopes M, Mitchell MC, Roche S, Muller JC, Bitar A, Sichez JP, van Effenterre R: Usefulness of intraoperative electrical subcortical mapping during surgery for low-grade gliomas located within eloquent brain regions: Functional results in a consecutive series of 103 patients. $J$ Neurosurg 98: 764-778, 2003.

8) Duffau H, Capelle L, Sichez N, Denvil D, Lopes M, Sichez JP, Bitar A, Fohanno D : Intraoperative mapping of the subcortical language pathways using direct stimulations. An anatomo-functional study. Brain 125: 199-214, 2002.

9) Duffau H, Denvil D, Capelle L: Long term reshaping of language, sensory, and motor maps after glioma resection: A new parameter to integrate in the surgical strategy. $J \mathrm{Neu}$ rol Neurosurg Psychiatry 72: 511-516, 2002.

10) Goldratt EM: The haystack syndrome. Sitting information out of data ocean. New York, North River Press, 1990.

11) Hess KR: Extent of resection as a prognostic variable in the treatment of gliomas. I Neurooncol 42:227-231, 1999 .

12）星田 徹，榊 寿右：皮質電気刺激による脳機能マッピ
ング. 高倉公朋編：脳神経外科の最先端 NO. 2,21 世紀の 新領域とニューテクノロジー。東京，先端医療技術研究 所, 2000, pp.261-268.

13) Iseki $H$, Muragaki $Y$, Taira $T$, Kawamata $T$, Maruyama $T$, Naemura K, Nambu K, Sugiura M, Hirai N, Hori T, Takakura K: New possibilities for stereotaxis. Informationguided stereotaxis. Stereotact Funct Neurosurg 76:159167, 2001.

14) Johnson PC, Hunt SJ, Drayer BP: Human cerebral gliomas: Correlation of postmortem MR imaging and neuropathologic findings. Radiology 170:211-217, 1989.

15) Karim AB, Afra D, Cornu P, Bleehan N, Schraub S, De Witte O, Darcel F, Stenning S, Pierart M, Van Glabbeke $\mathrm{M}$ : Randomized trial on the efficacy of radiotherapy for cerebral low-grade glioma in the adult: European Organization for Research and Treatment of Cancer Study 22845 with the Medical Research Council study BRO4:An interim analysis. Int J Radiat Oncol Biol Phys 52:316324, 2002.

16) Lacroix M, Abi-Said D, Fourney DR, Gokaslan ZL, Shi W, DeMonte F, Lang FF, McCutcheon IE, Hassenbusch SJ, Holland E, Hess K, Michael C, Miller D, Sawaya R: A multivariate analysis of 416 patients with glioblastoma multiforme: Prognosis, extent of resection, and survival. J Neurosurg 95: 190-198, 2001.

17) Luyken $C$, Blumcke I, Fimmers R, Urbach $\mathrm{H}$, Elger $\mathrm{CE}$, Wiestler OD, Schramm J: The spectrum of long-term epilepsy-associated tumors: Long-term seizure and tumor outcome and neurosurgical aspects. Epilepsia 44:822830, 2003.

18) Maruyama T, Muragaki Y, Iseki H, Kubo O, Mochizuki M, Seo S, Sakuma I, Hori T, Takakura K: Intraoperative detection of malignant gliomas using 5-Aminolevulic acid induced protoporphyrin fluorescence, openMRI and realtime navigation system. CARS2001:270-275, 2001.

19) Miwa $K$, Shinoda J, Yano H, Okumura A, Iwama T, Nakashima $\mathrm{T}$, Sakai N: Discrepancy between lesion distributions on methionine PET and MR images in patients with glioblastoma multiforme: Insight from a PET and MR fusion image study. J Neurol Neurosurg Psychiatry $\mathbf{7 5}$ : 1457-1462, 2004.

20) Moriarity JL, Boatman D, Krauss GL, Storm PB, Lenz FA: Human "memories" can be evoked by stimulation of the lateral temporal cortex after ipsilateral medial temporal lobe resection. J Neurol Neurosurg Psychiatry 71:549-551, 2001.

21）村垣善浩，丸山隆志，伊関 洋，堀 智勝：神経膠腫摘 出のための覚醒下手術。脳外速報 $14: 1187-119,2004$ 。

22）村垣善浩, 平沢研一, 山根文孝, 今村 強, 丸山隆志, 久保長生, 堀 智勝: 長期硬膜下電極埋め込みによる Mapping を利用した Eloquent Area 近傍 Glioma 摘出術。 嘉山孝正編：Advanced Technology を用いた脳腫瘍の外 科. 大阪，メディ力出版，2001，pp.140-148,

23) Muragaki Y, Suzukawa K, Iseki H, Maruyama T, Nambu K, Aramata $\mathrm{H}$, Sugiura $\mathrm{M}$, Naemura K, Hori T, Takakura K : Development of three-dimensional navigation system updated with intraoperative MRI. CARS2003: 1360, 2003.

24) Neuloh G, Pechstein U, Cedzich C, Schramm J: Motor evoked potential monitoring with supratentorial surgery. Neurosurgery 54: 1061-1072, 2004.

25) Nimsky C, Ganslandt O, Cerny S, Hastreiter P, Greiner G, Fahlbusch R: Quantification of, visualization, and compen- 
sation for brain shift using intraoperative magnetic resonance imaging. Neurosurgery $47: 1070-1080,2000$.

26) Nimsky C, Ganslandt O, Hastreiter P, Wang R, Benner T, Sorensen AG, Fahlbusch R: Intraoperative diffusion-tensor MR imaging: Shifting of white matter tracts during neurosurgical procedures -initial experience. Radiology 234: 218-225, 2005.

27) Ojemann GA: Neurosurgical management of epilepsy: A personal perspective in 1983. Appl Neurophysiol 46:11$18,1983$.

28) Ojemann JG, Miller JW, Silbergeld DL : Preserved function in brain invaded by tumor. Neurosurgery 39:253-259, 1996.

29) Pignatti F, van den Bent $M$, Curran D, Debruyne C, Sylvester R, Therasse P, Afra D, Cornu P, Bolla M, Vecht $\mathrm{C}$, Karim $\mathrm{AB}$ : Prognostic factors for survival in adult patients with cerebral low-grade glioma. J Clin Oncol 20: 2076-2084, 2002.

30) Pouratian N, Cannestra AF, Bookheimer SY, Martin NA, Toga AW: Variability of intraoperative electrocortical stimulation mapping parameters across and within individuals. J Neurosurg 101: 458-466, 2004.

31) Proescholdt MA, Macher C, Woertgen C, Brawanski A: Level of evidence in the literature concerning brain tumor resection. Clin Neurol Neurosurg 107: 95-98, 2005.

32) Quinones-Hinojosa A, Ojemann SG, Sanai N, Dillon WP, Berger MS : Preoperative correlation of intraoperative cortical mapping with magnetic resonance imaging landmarks to predict localization of the Broca area.J Neurosurg 99 : $311-318,2003$.

33) Report of brain tumor registry of Japan (1969-1993) 10th edition. Neurol Med Chir (Tokyo) 40:1-106, 2000.

34) Roux FE, Boulanouar K, Lotterie JA, Mejdoubi M, LeSage JP, Berry I: Language functional magnetic resonance imaging in preoperative assessment of language areas: Correlation with direct cortical stimulation. Neurosurgery 52: 1335-1347, 2003.

35) Sartorius CJ, Berger MS: Rapid termination of intraoperative stimulation-evoked seizures with application of cold Ringer's lactate to the cortex. Technical note. J Neurosurg 88: 349-351, 1998.

36) Shi WM, Wildrick DM, Sawaya R: Volumetric measurement of brain tumors from MR imaging.J Neurooncol $\mathbf{3 7}$ : 87-93, 1998.

37) Taylor MD, Bernstein $M:$ Awake craniotomy with brain mapping as the routine surgical approach to treating patients with supratentorial intraaxial tumors: A prospective trial of 200 cases. J Neurosurg $90: 35-41,1999$.

38) Ulmer JL, Hacein-Bey L, Mathews VP, Mueller WM, DeYoe EA, Prost RW, Meyer GA, Krouwer HG, Schmainda KM: Lesion-induced pseudo-dominance at functional magnetic resonance imaging: Implications for preoperative assessments. Neurosurgery 55:569-581, 2004.

39) Wada J, Rasmussen T: Intracarotid injection of Sodium Amytal for the lateralization of cerebral speech dominance. Experimental and clinical observations. J Neurosurg 17 : 266-282, 1960 .

40) Wiedemayer H, Fauser B, Sandalcioglu IE, Schafer H, Stolke D: The impact of neurophysiological intraoperative monitoring on surgical decisions: A critical analysis of 423 cases.J Neurosurg 96:255-262, 2002.

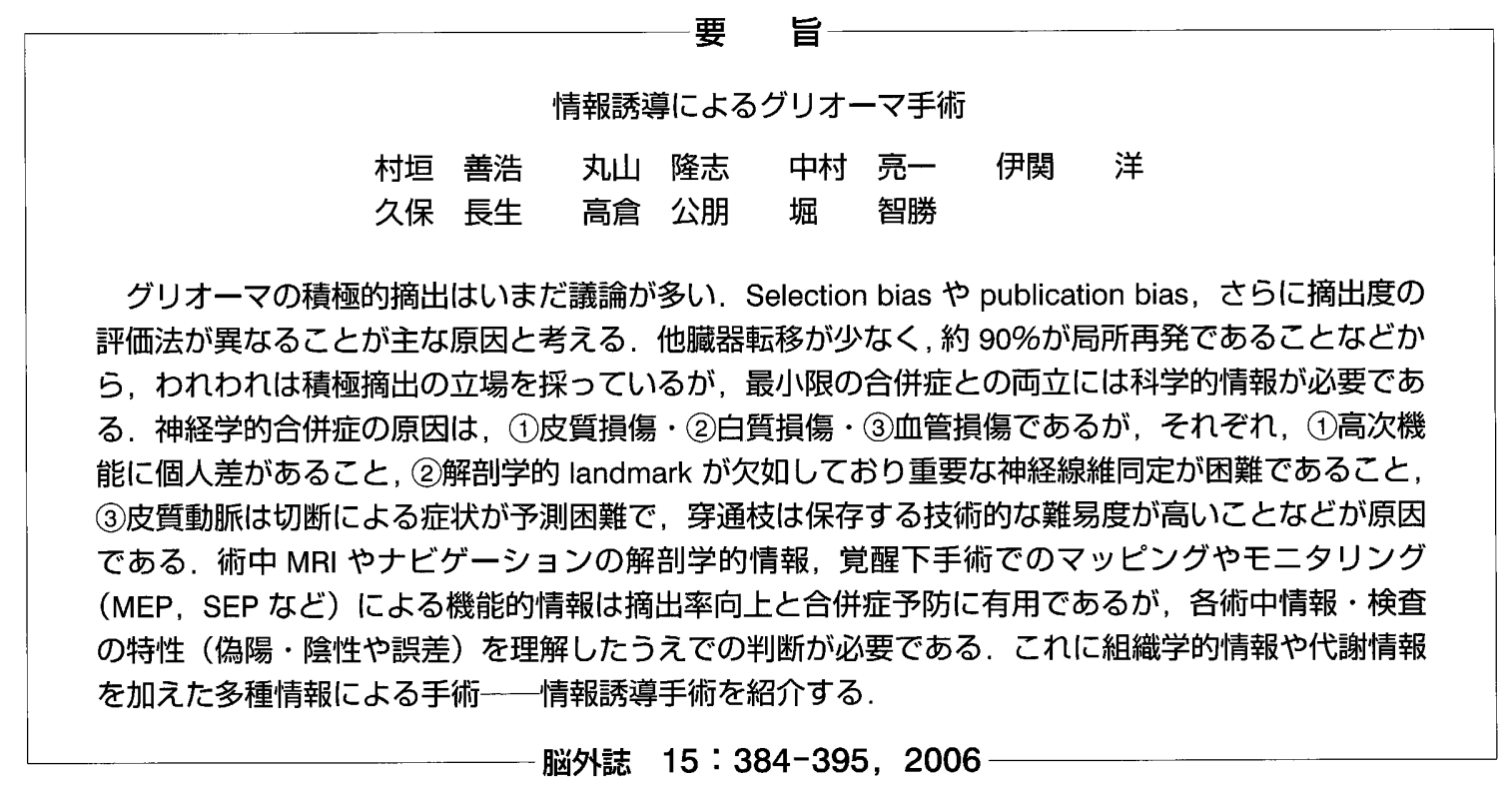

